DOI: 10.30519/ahtr.649639

Advances in Hospitality and Tourism Research (AHTR)

\title{
THE MEDIATING ROLE OF THE TOURISTS' CITIZENSHIP BEHAVIOR BETWEEN THE VALUE CO-CREATION AND SATISFACTION
}

\author{
Reşat ARICA ${ }^{1}$ \\ Adryaman University, Turkey \\ ORCID: 0000-0003-1238-7313
}

\author{
Abdülkadir ÇORBACI \\ Adryaman University, Turkey \\ ORCID: 0000-0003-3580-2698
}

\begin{abstract}
The purpose of this study was to determine the mediating role of the tourists' citizenship behavior between the value co-creation with customers and customer satisfaction. The data of the study was collected through a survey administered to the tourists who visited Antalya and purchased the touristic products through the co-creation. Confirmatory factor analysis, structural equation modeling analyses, and SPSS process extension analysis were carried out on 252 valid survey data collected from the sample. The results of the study showed that the value co-creation with customers was clustered in two factors: (i) experience quality value and (ii) individual value. The tourists' citizenship behavior consisted of four factors: (i) advocacy behavior, (ii) tolerance behavior, (iii) helping behavior and (iv) feedback behavior. According to another result of the study, the value co-creation with customers had a statistically significant and positive direct effect on customer satisfaction and the dimensions constituting the citizenship behavior of the tourists. Furthermore, it was concluded that the mediating effects of the advocacy and tolerance dimensions on the relationship between the value co-creation with customers and customer satisfaction were found to be statistically significant and positive.
\end{abstract}

\author{
Article History \\ Received 21 November 2019 \\ Revised 13 February 2020 \\ Accepted 13 February 2020
}

\section{Keywords \\ co-creation \\ value co-creation customer citizenship satisfaction tourism}

\footnotetext{
${ }^{1}$ Address correspondence to Reşat Arıca, Tourism Faculty, Adıyaman University, Adiyaman, TURKEY. E-mail: rarica@adiyaman.edu.tr
} 


\section{INTRODUCTION}

The businesses in the tourism sector seek ways to interact and cooperate with customers in practice (Park \& Ha, 2016). Co-creation is a business strategy used in the practices based on the cooperation with customers (Parks et al., 1981). Referring to the support of more than one and often different actors for the production at the sectoral scale through the cooperative and participatory practices (Phi \& Dredge, 2019, p. 281), cocreation is today accepted as a strategy that businesses use for ensuring the innovation, production and the interaction with customers (Bason, 2010). Businesses involve their customers in the production process in order to achieve more productive results from their customer-oriented initiatives. While the customers' participation in the production ensures their active role in the production process, it puts the role of value co-creation on the customers (Vargo \& Lusch, 2004; Prebensen \& Xie, 2017). In today's fastgrowing market where the customers are regarded as the dominant dynamic; the value creation goes beyond the businesses (Ulaga \& Chacour, 2001; Prahalad \& Ramaswamy, 2004), which makes it difficult for the businesses to create value independently from the customer (Arnould, 2008; Flores \& Vasquez-Parraga, 2015). This makes the customers one of the key components of the value co-creation. The value created with the participation of customers as a producer in the production activities is explained by the concept of mutual value creation in the literature. In this regard, value is accepted as one of the main outputs of the co-creation with customers (Ranjan \& Read, 2014; Flores \& Vasquez-Parraga, 2015). Customers' participation in the production not only puts the responsibility of functioning as the value-creator on their shoulder, but also allows them to affect the service outputs delivered and perceived (Ford \& Heaton, 2000; Arica \& Kozak, 2018; Phi \& Dredge, 2019). The opportunities provided by the co-creation in terms of supply and demand cause these concepts to be evaluated within different frameworks in the literature on tourism.

Co-creation effects service outputs in two ways. The first is to improve business outcomes, the second is to improve customers' perceptions. The basic assumption in these studies is that the co-creation with customers produces a value and this value has an effect on the service outputs such as quality (Grissemann \& Stokburger-Sauer, 2012; Prebensen et al., 2013; Bell \& Babyak, 2018), satisfaction (Namasivayam \& Guchait, 2013; Flores \& Vasquez-Parraga, 2015; Prebensen \& Xie, 2017; Assiouras et al., 2019), re-purchase (Fitzpatrick et al., 2013; Park \& Ha, 2016; Arıca \& Kozak, 2018), and customer citizenship behavior (Yi \& Gong, 2013; Assiouras et al., 2019; Gong \& Yi, 2019). Likewise, some researchers argue 
that in the tourism sector, the information shared between the business and customers nourish each other by means of the value co-creation with customers, thereby developing the service outputs through improving and personalizing services (Ford \& Heaton, 2000; Chan \& Guillet, 2011; Sugathan et al., 2017; Arıca \& Kozak, 2019). On the other hand, some researchers emphasize that the co-creation with customers may cause negative effects on the quality of the service outputs due to the following: complexity in the service processes and performance management; economic burdens; risk of failure to manage customer expectations and relationships; making it difficult to control strategic plans; and complicating the business management (Kelley et al., 1990; Ford \& Heaton, 2000; Hoyer et al., 2010). The value co-creation with customers is important in terms of not only its impacts, but also strengthening the behaviors (such as customer feedback, tendency to advocate the business, tolerance to the faults of the business) that express the belongingness of customers to the experience and business and, thereby, improving the customer satisfaction. The purpose of this research, was to determine the mediating role of tourists' citizenship behavior between the value co-creation with customers and the customer satisfaction. This study provides a path for future studies by focusing on the causal relationships between the value co-creation with customers, tourists' citizenship behavior, and the customer satisfaction. Furthermore, by virtue of the measurement model of the study, it will be possible for the touristic business managers to identify the strengths and weaknesses of the value co-creation with customers, customers' citizenship behavior, and the customer satisfaction. The data obtained in this regard will be able to be used in planning, monitoring, and evaluating the process of value cocreation with customers in the tourism businesses.

The structure of the research is as follows: In the literature section of the study, co-creation, value co-creation and customer citizenship behavior are explained. Then the framework for developing study hypotheses, data collection and analysis methods are explained. Finally, results were presented and discussions were made in line with the obtained findings.

\section{THEORETICAL BACKGROUND AND HYPOTHESIS DEVELOPMENT}

\section{Co-creation, value co-creation and customer citizenship behavior}

In the experience economy, co-creation is defined as a business strategy, the production structure composed of the producers but which allows the 
consumers to be a part of the production process (Oxenswardh, 2018, p. 38). Vargo and Lusch (2008) describe the co-creation as the involvement of two or more stakeholders in the production and consumption process and their engagement in the interaction, relationship, and communication within this process. Being the output of a process, the co-creation is realized by the contributions of different stakeholders. Whereas in the traditional paradigm, co-creation is realized through the inter-business cooperation; in the modern paradigm, the inter-customer cooperation and the cooperation between the business and customer are accepted as the common forms of production in the market (Li \& Petrick, 2008). Nevertheless, today, the most common form of production is the co-creation with customers in which the cooperation takes place between the business and the customer in the production process and the customers make an effort in the production process (Sugathan et al., 2017). Co-creation with customers refers to the active involvement of customers in the information production, information management, and experience production processes (Etgar, 2008). The companies' need for reaching the environmental resources and the technological developments are main factors in the development of the co-creation with customers in practice (Arnould, 2008; Sugathan et al., 2017). The technological developments have made it easy for businesses to reach the environmental resources through cooperation, interaction, and communication. This has created platforms where the customers produce information and create value among themselves through co-creation environments between the business and customer (Rihova et al., 2018; Buhalis \& Sinarta, 2019). Thus an important role and function is put on the customers as the co-creators in practice and, furthermore space is opened for development of practices where customers are encouraged to take the creator role. The framework of the concept of co-creation with customers, the development process of which has been associated with technology, has been drawn by the service-dominant logic.

The foundations of the concepts "co-creation", "co-creation with customers", and "value co-creation" in the academic literature were laid in the study carried out by Vargo and Lusch (2004) in which the transition from the product dominant logic into the service dominant logic was explained. In the study in question, a framework was drawn in order to understand the changes in the production patterns and the role of the customers in value creation (Li \& Petrick, 2008). According to the servicedominant approach, the developing momentum of the service economy and the increasing importance of knowledge and skills in the market increase the function of the operational resources in the production and marketing 
approaches of businesses (Vargo \& Lusch, 2004). Customers take part as the operational resources in various stages of production and consumption processes with their resources such as knowledge, skills, and effort and assume the role of co-creator for the companies. This approach, in which the business and the customers are considered together in the production, attributes the role of value co-creator to the customers as the operational resource in today's market structure (Li \& Petrick, 2008; Vargo et al., 2008). According to this approach, customers determine, create and purchase the value they created. On the other hand, the businesses are the element that prepares the value propositions and responds to the personalized demands of customers (Vargo et al., 2008). Vargo and Lusch (2004) interpret the customers' role as the value co-creator in two dimensions: value in use and value in exchange. While the value in use refers to the exchange of skills and services between the business and the customer in order to gain benefit; the value in exchange is explained as the benefit gained by the customers and businesses as a result of production (Vargo \& Lusch, 2004, p. 7). Prahalad and Ramaswamy (2004), who asserted that the value co-created with customers differed from the traditional value creation approach and placed the value at the center of experience, significantly contributed to the development of the concept of value co-creation with customers. Researchers associate the value co-creation with customers with the consumer experience theory and explain it by the changing role of the customer in the industrial system. The changing role of customers in the industrial system transforms the value creation from being product- and business-oriented into being customer-oriented. Accordingly, today, the value creation consists of a combination of internal and external resources with customers playing an important role in value creation as the external resource. Prahalad and Ramaswamy (2004, p. 8) explain the building blocks of interaction in the value co-creation with customers by the DART (Dialogue-Access-Risk Assessment-Transparency) model. Different combinations in the DART model are important for the development of business capabilities, the development of relationships between the customer and the business, and a more efficient and effective value creation process.

More recent research suggests that customer value creation behavior could be considered as a customer citizenship behavior, which focuses on the extra-role behavior that provides extraordinary value to the firm (Yi \& Gong, 2013; Arica \& Kozak, 2019; Assiouras et al., 2019). Van Doorn et al. (2010) propose that customer behaviors such as making suggestions to improve the service experience, helping service employees, and helping 
other customers are all aspects of customer value creation behavior. Ford (1995) argues that like employees, customers engage in a variety of citizenship behaviors such as reporting problems to employees, recommending a place of business to friends, or displaying a bumper sticker advertising their support for an organization. Assiouras et al. (2019) explain some initiatives of customers by the citizenship behavior. In these initiatives, the customers assume extra responsibilities, apart from the cocreation role, and take some actions towards other customers, employees and/or firms. The customer citizenship behavior is related to their attitudes and behaviors both before and after the production and directly affects the position of the companies in the market (Groth, 2004). Groth (2004) explained the dimensions of customer citizenship behavior in three categories: recommending helping and providing feedback. In evaluating the customer citizenship behavior in terms of participation in production, Yi and Gong (2013) explain the citizenship behavior through four factors: feedback, advocacy, helping, and tolerance. Arıca and Kozak (2019) evaluated the customer citizenship behavior in terms of participation in production and discussed it through behaviors such as advocacy, helping and feedback.

The findings in the literature on the dimensions of citizenship behavior have been similar and these dimensions were explained by Yi and Gong (2013). According to these researchers, feedback is the evaluation of the products and the employee attitudes co-created with the customer in order to provide better service to the customers. Advocacy refers to the attitudes and behaviors voluntarily displayed by the customers for the successful cocreation practices. Helping is the case where some customers feel responsible for eliminating the difficulties that other customers, who purchased the same product, experience. Tolerance explains the case where the customer behaves patiently when the customers' requests are not met by the business and there are some unexpected service failures (Yi \& Gong, 2013, p. 1280-1281). When considered in terms of tourism sector, the customer citizenship is related to the followings: tourists' behavior towards the problems experienced during the service; support to the business and other tourists in finding solution to the problems; attitude in the process of online and offline information-sharing about the business and the experience during and after the experience (Assiouras et al., 2019). While the positive support of the tourists to the business adds value to the touristic experience and the business; the negative support worsens the problems and negatively affects the quality of the experience and thus, the customer satisfaction. Since the posts shared by the tourists about their experience 
and the business affect the decision making process of the potential tourists, especially in today's developing social communication networks; the quality of the posts shared in these networks by the tourists who experienced a service will be one of the important determinants of the competitiveness and continuity of the business (Law et al., 2014; Rihova et al., 2018; Buhalis \& Sinarta, 2019).

\section{Effect of value co-creation on the customer citizenship behaviors and customer satisfaction}

Co-creation with customers explains the value creation through cooperation and partnerships (Prebensen \& Xie, 2017). By taking part in the production activities, customers carry out value-creation activities for both themselves and the potential customers. Value co-creation with customers is one of the business strategies that make it possible to align the productions with the customer's requests and needs (Prebensen \& Xie, 2017; Phi \& Dredge, 2019). The businesses and customers cooperate in value creation activities, and their basic expectation from this process is to gain benefit. Mutual benefit is the main purpose of the value co-creation with customers (Vargo \& Lusch, 2004; Chan et al., 2010). While the tourism businesses aim to improve the quality of services they offer through the mutual value creation, and by doing so, generate revenue, profit, and competitiveness and thus ensure their continuity; the tourists, through the mutual value creation, expect to receive high quality and satisfying services that are in line with their requests and needs. The more the benefit expectations of the tourists are met in the mutual value creation process, the more their belonging to the process increases (Ford \& Heaton, 2000; Groth, 2004; Assiouras et al., 2019). The tourists who have a high level of citizenship behavior tend to re-choose the business, provide feedback about the business and advocate for the business in online and offline platforms (Groth, 2004; Barnes et al., 2014). Furthermore, the tendency of the tourists, who develop a citizenship behavior, to help other tourists in the experience process increases (Groth, 2004; Assiouras et al., 2019; Gong \& Yi, 2019). Therefore, it is expected that the value co-creation with customers improves the citizenship behavior of tourists. In this regard, it is assumed in the literature that the value co-creation with customers is related to the behaviors such as advocacy, feedback, recommendation, and helping, which constitute the dimensions of the citizenship behavior. Within this framework, the hypotheses of this study are as follows: 
$\mathrm{H}_{1}$ : Value co-creation with customers directly and positively affects the advocacy behavior of tourists.

$\mathrm{H}_{2}$ : Value co-creation with customers directly and positively affects the tolerance behavior of tourists.

$\mathrm{H}_{3}$ : Value co-creation with customers directly and positively affects the helping behavior of tourists.

$\mathrm{H}_{4}$ : Value co-creation with customers directly and positively affects the feedback behavior of tourists.

In general, satisfaction is defined as the contentment felt by the customers from the services and the positive feelings towards the service (Blazquez-Resino et al., 2015, p. 711). Etgar (2008) emphasizes that the value co-creation with customers can improve the customer satisfaction by means of ensuring the identification of the customer demands, requests, and needs that are difficult to predict and meet. Another view asserts that ignoring the knowledge and skills offered by the customers during the process of value co-creation with customers leads to the dissatisfaction (Ford \& Heaton, 2000). In the literature on tourism, the widely accepted view is that the cocreation with customers improves the satisfaction (Namasivayam \& Guchait, 2013; Prebensen \& Xie, 2017; Assiouras et al., 2019). However, in some studies, it has been argued that the effect of the value co-creation with customers on satisfaction may vary depending on the mediating variables. In this regard, there have been some findings asserting that the perceived value (Chan et al., 2010; Prebensen et al., 2015) and quality (Prebensen et al., 2013; Bell \& Babyak, 2018; Arıca \& Kozak, 2019) have a mediating effect on the value co-creation with customers and the customer satisfaction. Likewise, it has been argued in the literature on tourism that the development of citizenship behavior through the value co-creation with tourists improves satisfaction (Assiouras et al., 2019). The view supported in the literature is that the value co-creation with tourists has both direct and indirect effects on satisfaction. Within the framework of these assumptions, the following hypotheses will be tested in this study:

$\mathrm{H}_{5}$ Value co-creation with customers directly and positively affects the satisfaction of tourists.

$\mathrm{H}_{6}$ : The dimensions of the citizenship behavior of tourists have a positive mediating role between the value creation with customers and the satisfaction.

The theoretical model proposed in the current study determined in the axis of hypotheses is presented in Figure 1. 


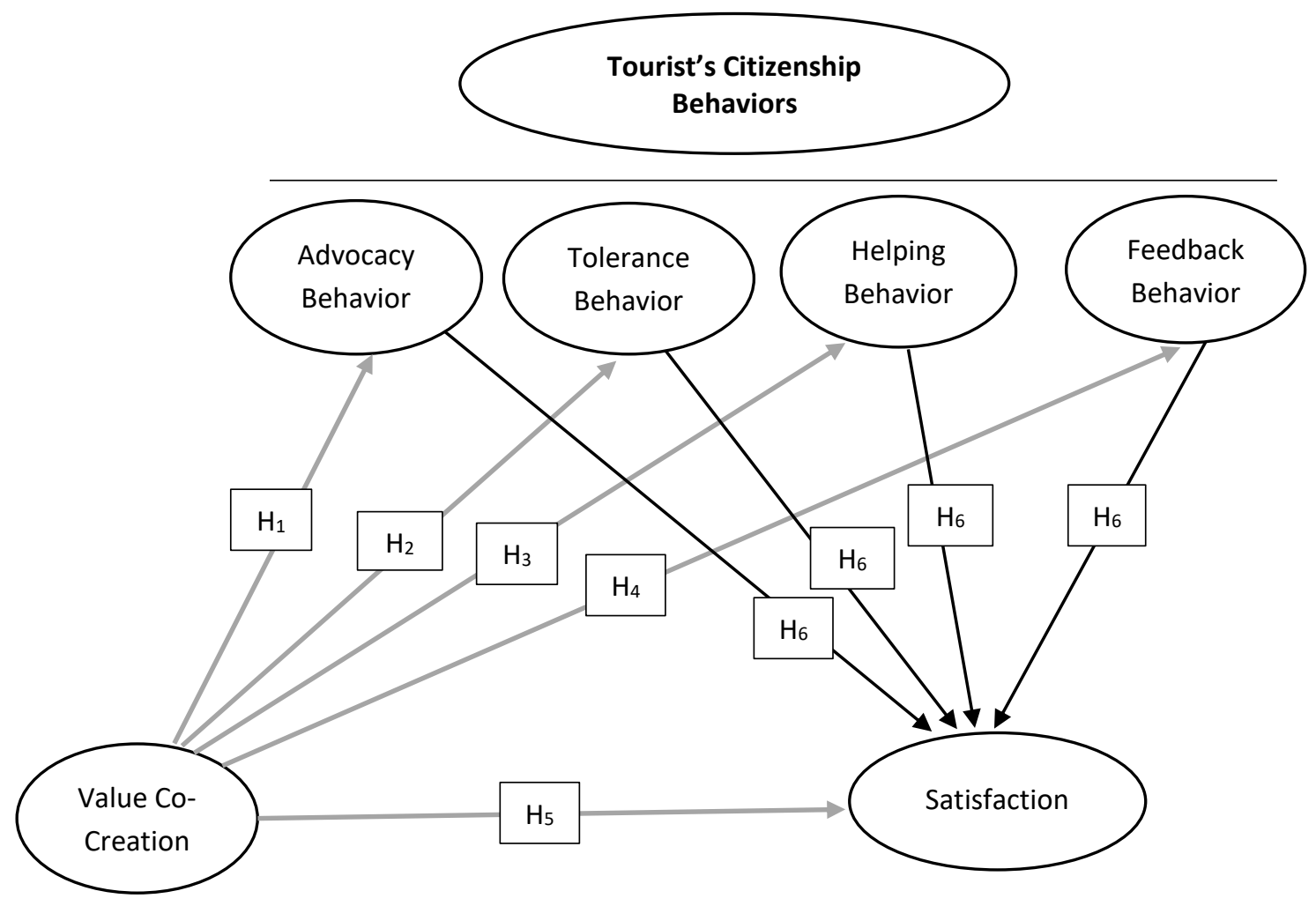

Figure 1. Theoretical Model

In the literature examining the direct and indirect effects of the value co-creation with customers on the service outputs delivered and perceived; there is a gap in terms of evaluating the effects of the value co-creation with customers on the willingness to engage in the citizenship behavior and the effects of citizenship behavior on the perceived service outcomes such as customer satisfaction (Groth, 2004; Assiouras et al., 2019; Gong \& Yi, 2019). The research was carried out on local tourists. In the literature, the participation of tourists in production, especially in developed countries, and the impact of participation on business and customer outcomes were evaluated and different results were achieved (Park \& Ha, 2016; Phi \& Dredge, 2019). These researches were carried out especially in developed countries where co-creation implementation strategies are integrated into business structures. However, in developing countries, co-creation strategies are not used adequately in businesses in the tourism sector. In this context, determining the effect of the co-creation strategy on the service outputs in developing countries is important in the context of providing clues regarding the future business structures. 


\section{METHODOLOGY}

\section{Survey Instrument}

Questionnaire was used as the data collection tool in this study. The questionnaire form was created by benefiting from the studies in the literature. The data collection tool used in the study consists of four parts. The first part is composed of the statements measuring the value co-creation with customers. These statements were created using the measurement models developed by Chan et al. (2010) and Flores and Vasquez-Parraga (2015). The statements in the second part of the data collection tool measure the citizenship behavior of the tourists. The statements measuring the citizenship behavior of the tourists were adapted from the measurements model developed by Yi and Gong (2013) and Assiouras et al. (2019). The third part consists of the statements on satisfaction, which were adapted from study carried out by Chan et al. (2010). In total, 32 questions adapted from these studies constitute the measurement tool of the research. In the fourth part, there are some variables that make it possible to determine the demographic characteristics of the participants (age, gender, educational background, occupation, marital status, and income level). Since this study was to be carried out with the participation of the domestic tourists in Turkey, the measurement tools were translated into Turkish. Furthermore, in order to test the intelligibility of the statements, the opinions were received from 20 academic experts. Following this process, the corrections proposed for the questionnaire were made and the questionnaire used in the study was finalized. Five-point Likert scale was used in the questionnaire (1-Strongly Disagree, 5- Strongly Agree).

\section{Data Collection}

The data of the study were collected using the survey method. The survey was administered to the tourists who visited Antalya between 10 June 2019 - 20 August 2019. Antalya was preferred due to being one of the top tourist attraction places in Turkey. The sample of study is consisting of local tourists who purchased tour from travel agency through the co-creation. Tourists who participate in any stage of co-creation and buy private tours from travel agencies were preferred. The data were collected in this region from 252 tourists identified by purposive sampling method. During the determination of the tourists participating in the study, the co-creation status of the tourists was evaluated with three pre-test questions. These questions are: (i) We produced tour together with the travel agency, (ii) I 
have contributed to the production process intellectually, (iii) I have contributed to the production process with my experience. In the process of preparing the data for the analysis, first of all, the questionnaires were reviewed and the forms having contradictory and incomplete answers were considered invalid. In the second phase, the mean and standard deviation values which were not within the possible limits were examined and the missing data were checked through the descriptive analyzes conducted for the data set. The questionnaires (17) that caused problems due to the missing data were removed from the data file. In the third phase, the extreme values that could cause critical problems in the analyzes were determined. Extreme values may arise from the errors in data entry and the situations in which the subject is different from the rest of the sample and is not a member of the population from which it is selected (Tabachnick \& Fidell, 1996). The data set of the research was cleared from the extreme values which may disrupt the results of the statistical tests. Based on the recommendation that the data out of the \pm 3 standard deviation values should be excluded (Çokluk et al., 2016), the data which had extreme means greater than +3 or smaller than -3 standard deviation, were excluded from the research sample. Finally, in order to prepare the data for the analysis, the distribution probabilities were evaluated with the normal distribution criterion (Alpar, 2010). In the research, the conformity of the data to the normal distribution was examined with univariate normality, coefficient of kurtosis and skewness. Although there is no commonly accepted standards in the literature about the normal distribution, it is stated that when the skewness and kurtosis values are between -2 and +2 , the normal distribution assumption is valid (Kalayc1, 2016). When the data of the research were subjected to normal distribution test, it was seen that the skewness and kurtosis values of all questionnaire expressions were in the appropriate range. After these findings, the descriptive statistics such as percentage and frequency analysis were used primarily in the analysis of the data set in order to determine the characteristics of the tourists in the sample. Then, the factor structure of the data set was determined and confirmed by applying the Confirmatory factor analysis to the data set. After structural equation modeling analyses, and SPSS process extension analysis were carried out on 252 valid survey data collected from the sample. 


\section{FINDINGS}

\section{Sample Characteristics}

When the demographic characteristics of the tourists are examined, it is observed that their ages vary between 19 and 68, but the majority (42.0\%) is in the age group of $30-39$. Besides, the ratio of female $(44.4 \%)$ and male (55.6\%) participants are close to each other, and the findings regarding their educational status indicate that the education level of the participants is high. $5.2 \%$ of the tourists participating in the research had a lower level of education than the high school, $14.6 \%$ of them had high school education, and $80.2 \%$ of them graduated from an associate degree, graduate or postgraduate program. Also, when the employment status of the participants was considered, it was observed that almost $90 \%$ of the participants were employed either in public or private sector. On the other hand, the participants had a substantially varying income structure, it was found that $5.6 \%$ of them had minimum wage or lower income. A significant part $(90.0 \%)$ of this aforementioned $5.6 \%$ is composed of the housewives and students without income.

Table 1. Demographic Characteristics of the Respondents

\begin{tabular}{|c|c|c|}
\hline Age & Frequency & Percentage \\
\hline $19-29$ & 72 & 28.6 \\
\hline $30-39$ & 106 & 42.0 \\
\hline $40-49$ & 50 & 19.9 \\
\hline 50 and above & 24 & 9.5 \\
\hline \multicolumn{3}{|l|}{ Gender } \\
\hline Female & 112 & 44.4 \\
\hline Male & 140 & 55.6 \\
\hline \multicolumn{3}{|l|}{ Education } \\
\hline High School and Below & 50 & 19.8 \\
\hline Associate Degree & 29 & 11.5 \\
\hline Graduate Education & 137 & 54.4 \\
\hline Postgraduate Education & 36 & 14.3 \\
\hline \multicolumn{3}{|l|}{ Occupation } \\
\hline Public Sector & 131 & 52.0 \\
\hline Private Sector & 92 & 36.5 \\
\hline Housewife & 13 & 5.2 \\
\hline Retired & 9 & 3.6 \\
\hline Student & 7 & 2.8 \\
\hline \multicolumn{3}{|l|}{ Marital Status } \\
\hline Married & 129 & 51.2 \\
\hline Single & 123 & 48.8 \\
\hline \multicolumn{3}{|c|}{ Monthly Income (in Turkish Lira) } \\
\hline $0-2000 \mathrm{TL}$ & 14 & 5.6 \\
\hline 2001-4000 TL & 71 & 28.1 \\
\hline $4001-6000 \mathrm{TL}$ & 107 & 42.5 \\
\hline $6001 \mathrm{TL}$ and above & 60 & 23.8 \\
\hline Total & 252 & 100 \\
\hline
\end{tabular}




\section{Findings of Confirmatory Factor Analysis}

In the first stage of structural equation modeling, the confirmatory factor analysis was applied to the measurement models. Confirmatory factor analysis is a test method generally used in the scale development and validity analyses or in the validation of a predetermined structure (Yaşlioğlu, 2017, p. 78). In this study, the confirmatory factor analysis was individually applied to test the validity of each measurement model explaining the value co-creation with customers, the tourists' citizenship behavior, and their satisfaction. Within this framework, first of all, the statistical significance of the model-data compatibility was evaluated using the fit indices. When the statistical significance of the model-data compatibility was evaluated using the fit indices of the measurement models of the value co-creation with customers, the tourists' citizenship behavior, and the satisfaction; after the recommended modifications, all the values were found to be within the acceptable fit range (See Table 2).

Table 2. The Fit Indices of the Measurement Models

\begin{tabular}{lccccccc}
\hline Measurement Models & $\chi \mathbf{2} / \mathbf{s d}$ & $\mathbf{p}$ & $\mathbf{N F I}$ & $\mathbf{C F I}$ & GFI & AGFI & RMSEA \\
Value Co-Creation & 2.346 & .000 & 0.931 & 0.958 & 0.949 & 0.904 & 0.07 \\
Customer Citizenship Behavior & 2.361 & .000 & 0.894 & 0.954 & 0.916 & 0.889 & 0.07 \\
Satisfaction & 3.829 & .003 & 0.976 & 0.982 & 0.976 & 0.909 & 0.09 \\
\hline
\end{tabular}

In addition to the model-data fitness, the structural reliability and the explained variance values of the measurement models of the value cocreation with customers, the tourists' citizenship behavior, and the satisfaction were calculated. The structural reliability of the measurement models of the value co-creation with customers, the tourists' citizenship behavior, and the satisfaction were determined to be $0.89,0.91$, and 0.88 , respectively. As a result of the confirmatory factor analysis, the variance explained by the two-factor structure in the measurement model of the value co-creation with customers was determined to be 0.46 ; the variance explained by the four-factor structure expressing the tourists' citizenship behavior was determined to be 0.54 ; and the variance explained by the satisfaction dimension was determined to be 0.57 . 
Table 3. Confirmatory Factor Analysis

\begin{tabular}{|c|c|c|c|}
\hline & $\begin{array}{c}\text { Composite } \\
\text { Reliability (CR) }\end{array}$ & $\begin{array}{l}\text { Average Variance } \\
\text { Extracted (AVE) }\end{array}$ & $\begin{array}{c}\text { Square root of } \\
\text { the AVE }\end{array}$ \\
\hline Value Co-Creation & 0.89 & 0.46 & 0.678 \\
\hline Value of Experience Quality & 0.80 & 0.50 & 0.707 \\
\hline Individual Value & 0.82 & 0.44 & 0.663 \\
\hline $\begin{array}{c}\text { Customer Citizenship } \\
\text { Behavior }\end{array}$ & 0.91 & 0.54 & 0.735 \\
\hline Advocacy Behavior & 0.82 & 0.54 & 0.735 \\
\hline Tolerance Behavior & 0.83 & 0.62 & 0.787 \\
\hline Helping Behavior & 0.81 & 0.51 & 0.714 \\
\hline Feedback Behavior & 0.79 & 0.55 & 0.742 \\
\hline Satisfaction & 0.88 & 0.57 & 0.755 \\
\hline
\end{tabular}

\section{Test of the Hypotheses}

The theoretical models and hypotheses developed within the scope of the study were examined using the structural equation modeling. Structural equation modeling is a statistical technique that reveals and tests the relationships between the multiple, independent, and dependent implicit variables, each of which can be measured with more than one observable variable. It incorporates the measurement errors into the model and takes into account the measurement errors correlated with each other (Taşkın \& Akat, 2010). The values showing the integrity and fitness of the structural equation modeling created between the measurement models of the value co-creation with customers, the tourists' citizenship behavior, and the satisfaction were given in the Table 4.

Table 4. Fit Indices $(\mathrm{n}=252)$

\begin{tabular}{lllllll}
\hline$\chi 2 / \mathbf{s d}$ & $\mathbf{p}$ & NFI & CFI & GFI & AGFI & RMSEA \\
2.137 & .000 & 0.879 & 0.94 & 0.895 & 0.845 & 0.067 \\
\hline
\end{tabular}

When the fit values are examined, it is seen that the values are within the acceptable limits. This finding indicates that there is no difference between the covariance matrix and the sample covariance matrix of the theoretical relational model, in other words, the theoretical model fits the sample data. Cronbach's Alpha $(\alpha)$ coefficient, which was used to 
determine the internal consistency of the data set, was calculated to be 0.929 . This value $(\alpha)$ indicates that the data set is reliable. Convergent validity and discriminant validity techniques were used to determine the consistency and validity of the model. Convergent validity was evaluated taking into account the variance explained by the measurement models. In this regard, the variance explained in the measurement model of the value co-creation with customers was determined to be 0.46 ; the variance explained by the structure in the tourists' citizenship behavior was determined to be 0.54 ; and the variance explained by the structure of the satisfaction was determined to be 0.57 . While Hair et al. (2010) suggest that the variances equal to or above 0.50 are acceptable; in the literature, it is argued that the variances equal to or above 0.40 could be acceptable (Huang et al., 2013). When the variance explained by the measurement models is considered, it is seen that the convergent validity of the scale is ensured. The FornellLarcker criterion was used for discriminant validity. Accordingly, if the multiple correlations of the structure do not exceed the square root of the explained variance, the distinctive validity is ensured (Fornell \& Larcker, 1981 , p. 45). The correlation values obtained as a result of the analyzes are given in Table 5.

Table 5. Means, Standard Deviations and Correlations of the Constructs

\begin{tabular}{lcccccccc}
\hline & Mean & SD & 1. & 2. & 3. & 4. & 5. & 6. \\
1. Value Co-Creation & 4.01 & 0.505 & 0.678 & & & & & \\
2. Advocacy Behavior & 4.12 & 0.583 & 0.487 & 0.735 & & & & \\
3. Tolerance Behavior & 3.69 & 0.659 & 0.518 & 0.558 & 0.787 & & & \\
4. Helping Behavior & 4.09 & 0.572 & 0.537 & 0.435 & 0.397 & 0.714 & & \\
5. Feedback Behavior & 4.06 & 0.629 & 0,469 & 0,347 & 0,302 & 0.551 & 0.742 & \\
6. Satisfaction & 4.20 & 0.515 & 0.458 & 0.346 & 0.429 & 0.443 & 0.486 & 0.755 \\
\hline
\end{tabular}

After ensuring the validity and reliability of the measurement model which evaluated the effect of the value co-creation with customers on the dimensions of the tourists' citizenship behavior and the effect of the value co-creation with customers on the satisfaction through the dimensions of the tourists' citizenship behavior; the hypotheses of the study were tested. The direct effect of the value co-creation with customers on the dimensions of the tourists' citizenship and the customer satisfaction was calculated and the values obtained were showed in the model (See Figure 2). Accordingly, it is seen that there are direct effects between the measurement models constructed of the latent variables in the path chart. The mediating effects were analyzed by SPSS Process Extension. It was found that the effect of the 
value co-creation with customers on the satisfaction through the advocacy and tolerance behavior was statistically significant and positive.

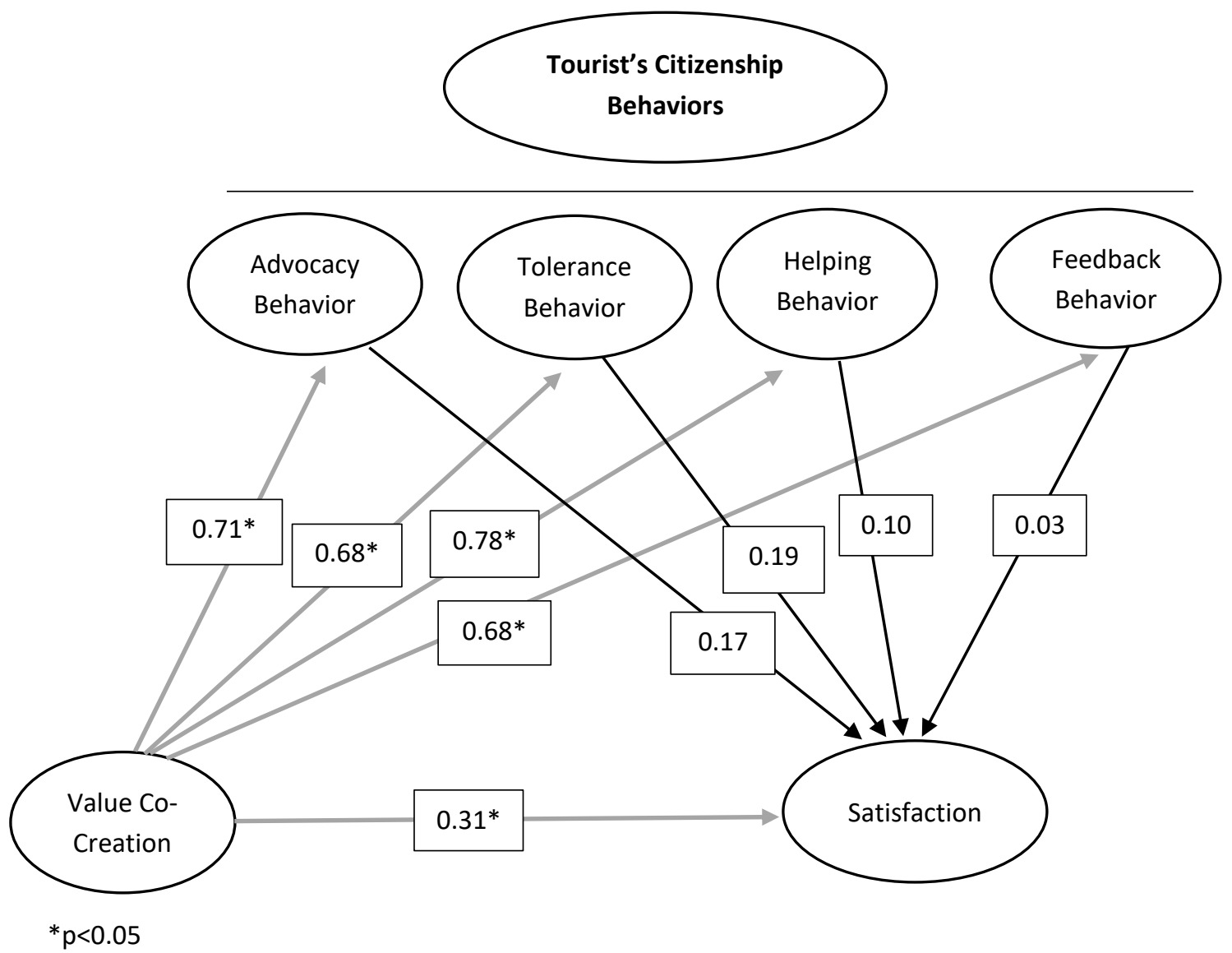

Figure 2. Structural Model

In the path chart given in the Figure 2, it is seen that there are direct effects between the measurement models constructed of the latent variables. Based on the findings reached in the study, it can be stated that the value co-creation with customers has direct effects on the dimensions explaining the tourists' citizenship behavior and the customer satisfaction. Accordingly, the value co-creation with customers has a direct, significant, and positive effect on the dimensions of the tourists' citizenship behavior and the customer satisfaction. The standardized regression coefficient between the value co-creation with customers and the advocacy behavior (H1) is $\beta=0.71$. In other words, a one-unit increase in the value co-creation with tourists will lead to a 0.71-unit increase in the advocacy behavior exhibited for the business. Similarly, the standardized regression coefficients between the value co-creation with customers and the dimensions "tolerance behavior (H2)", "helping behavior $(\mathrm{H} 3)^{\prime}$ ", and "feedback behavior $(\mathrm{H} 4)$ " were found to be $(\beta=0.68),(\beta=0.78)$, and $(\beta=$ 
0.68), respectively. All these findings reveal that the value co-creation with customers has a statistically significant and positive effect on the dimensions of the tourists' citizenship behavior. On the other hand, the standardized regression coefficient between the value co-creation with customers and the satisfaction (H1) is $\beta=0.31$. In other words, a one-unit increase in the value co-creation with tourists will lead to a 0.31-unit increase in the customer satisfaction. It was also found that the behaviors "advocacy (0.10)" and "tolerance (0.13)" had a statistically significant and positive mediating effects on the relationship between the value co-creation with customers and the satisfaction. Accordingly, a one-unit increase in the participation of the customers in the value co-creation will lead to a 0.10unit increase in the customer satisfaction through the advocacy behavior. Furthermore, a one-unit increase in the participation of the customers in the value co-creation will lead to a 0.13-unit increase in the customer satisfaction through the tolerance behavior. Hypotheses and their support status are presented in Table 6.

Table 6. Supported and Unsupported Status of Research Hypotheses

\begin{tabular}{|c|c|c|c|}
\hline Hypotheses & $\beta$ & $\mathbf{p}$ & Results \\
\hline $\begin{array}{l}\text { H1: Value co-creation with customers directly and positively affects the } \\
\text { advocacy behavior of tourists. }\end{array}$ & 0.71 & .004 & Supported \\
\hline $\begin{array}{l}\mathrm{H}_{2}: \text { Value co-creation with customers directly and positively affects the } \\
\text { tolerance behavior of tourists. }\end{array}$ & 0.68 & .000 & Supported \\
\hline $\begin{array}{l}\mathrm{H}_{3}: \text { Value co-creation with customers directly and positively affects the helping } \\
\text { behavior of tourists. }\end{array}$ & 0.78 & .000 & Supported \\
\hline $\begin{array}{l}\mathrm{H}_{4}: \text { Value co-creation with customers directly and positively affects the feedback } \\
\text { behavior of tourists }\end{array}$ & 0.68 & .001 & Supported \\
\hline $\begin{array}{l}\text { H5: Value co-creation with customers directly and positively affects the } \\
\text { satisfaction of tourists. }\end{array}$ & 0.31 & .005 & Supported \\
\hline \multicolumn{4}{|l|}{$\begin{array}{l}\mathrm{H}_{6} \text { : The dimensions of the citizenship behavior of tourists have a positive } \\
\text { mediating role between the value co-creation with customers and the } \\
\text { satisfaction. }\end{array}$} \\
\hline $\begin{array}{l}\text { - } \mathrm{H}_{6} \text { : Advocacy behavior has positive mediation role between the value co- } \\
\text { creation with customers and the satisfaction. }\end{array}$ & 0.12 & .002 & Supported \\
\hline $\begin{array}{l}\text { - } \mathrm{H}_{6} \text { : Tolerance behavior has positive mediation role between the value co- } \\
\text { creation with customers and the satisfaction. }\end{array}$ & 0.13 & .023 & Supported \\
\hline $\begin{array}{l}\text { - } \mathrm{H}_{6} \text { : Helping behavior has positive mediation role between the value co- } \\
\text { creation with customers and the satisfaction. }\end{array}$ & 0.10 & .138 & Unsupported \\
\hline $\begin{array}{l}\text { - H6: Feedback behavior has positive mediation role between the value co- } \\
\text { creation with customers and the satisfaction. }\end{array}$ & 0.06 & .326 & Unsupported \\
\hline
\end{tabular}




\section{DISCUSSION}

The primary focus of the study was to test the research model, the basic variables of which were developed based on the models and scales in the literature. Within this framework, the effect of the value co-creation with customers on the tourists' citizenship behavior and satisfaction was examined. When the relevant literature is examined, it is seen that the effect of the value co-creation with customers on the service outputs such as quality (Prebensen et al., 2013; Bell \& Babyak, 2018), satisfaction (Groth, 2004; Flores \& Vasquez-Parraga, 2015; Prebensen \& Xie, 2017; Assiouras et al., 2019), and re-purchase (Fitzpatrick et al., 2013; Park \& Ha, 2016; Arıca \& Kozak, 2018) has been questioned. Going beyond this, in this study, a model was developed from a holistic point of view to evaluate the effect of the value co-creation with customers on the citizenship behavior and satisfaction of the tourists, which are important both during and after the experience.

The results of the study showed that the value co-creation with customers had a positive and direct effect on the dimensions constituting the citizenship behavior of tourists. These results are in line with the relevant literature. Similar to this result, Groth (2004) found that customers' co-creation with customers affects customer citizenship behavior. Yi and Gong (2013) explained the value co-creation with customers through the participation behavior and citizenship behavior and found that the value co-creation with customers positively affected the citizenship behavior. Likewise, Assiouras et al. (2019) found that there was a relationship between the value co-creation with customers and the customer citizenship behavior. In the present study, the effect of value co-creation with customers on the customer satisfaction was found to be significant and positive. This result is in line with the relevant literature (Flores \& VasquezParraga, 2015; Prebensen \& Xie, 2017; Assiouras et al., 2019). However, some researchers found that the value co-creation with customers negatively affected the satisfaction (Parks et al., 1981; Etgar, 2008; Ford \& Heaton, 2000; Arıca \& Kozak, 2018). In this regard, this study differs from the literature. As a matter of fact, the case in which the tourists exert effort for and provide support to the production process, but do not find the desired products as a result of this process will negatively affect the satisfaction level. It is obvious that the different results obtained from different studies contribute to and enrich the literature from different perspectives. Furthermore, in this study, it was concluded that the value cocreation with customers positively affected the satisfaction through some dimensions of the tourists' citizenship behavior, that is, the advocacy and 
tolerance. Based on all these findings, it was proved that the research model, supported by the results obtained from empirical data and analyses, was feasible. A contribution was made to the literature on tourism with the model validated in this study.

The findings of the study showed that the value co-creation with customers had a two-dimensional structure, consisting of the experience quality value and the individual value. In many studies in the literature, the value co-creation with customers has been discussed on the basis of a multidimensional structure (Prebensen et al., 2015; Park \& Ha, 2015; Prebensen \& Xie, 2017; Assiouras et al., 2019). In these studies, it was asserted that the value co-creation with customers created a quality of experience by means of enhancing the quality standards perceived, the performance expected, and the benefit obtained by the customer (Cassia et al., 2014, p. 54) and that it created an individual value by means of providing a sense of achievement, prestige, personal development, and satisfaction (Flores \& Vasquez-Parraga, 2015, p. 16). In this regard, it is seen that the results of the study are similar to the results reached in the related literature. However, in this study, it was found that the tourists' citizenship behavior had a multidimensional structure. These dimensions are the behaviors of advocacy, tolerance, feedback, and helping. In the previous studies, Yi and Gong (2013) and Assiouras et al. (2019) determined the dimensions of advocacy, tolerance, feedback, and helping in customer citizenship behavior. On the other hand, Arıca and Kozak (2019) identified the main dimensions of the customer citizenship behavior as advocacy, helping, and feedback. These results show that the dimensions specified in this study overlap with the literature.

Based on the direct effect analyses carried out within the scope of the study; it was concluded that the value co-creation with customers had a positive effect on the advocacy, tolerance, feedback, and helping behaviors of tourists. Likewise, in the studies carried out by Yi and Gong (2013) and Assiouras et al. (2019), it was found that there was a relationship between the value co-creation with customers and the customer citizenship behavior. Considering within the framework of the previous studies, it is seen that the results of this study are similar to those in the literature. Assiouras et al. (2019) explain the effect of the value co-creation with customers on the citizenship behavior as follows: The customer participation in production makes it possible for the customers to align the production with their requests and needs and allow them to attach value to what is unique to them. The customers' creation of value unique to them encourages them to show belongingness to the business and the experience 
process and to display behaviors that can contribute to the business and the experience process by means of undertaking voluntary, optional, and extra responsibilities that are not required in the production process (Groth, 2004). When the mediating structures established in the study were examined, it was found that the behaviors "advocacy" and "tolerance" had a mediating role in the positive effect of the value co-creation on the customer satisfaction. The satisfaction levels of individuals, who tolerate the experience and business faults and tend to advocate the business in a positive way, are also high (Gong \& Yi, 2019). In this regard, it can be stated that the results obtained in this study overlap with the literature.

Furthermore, the findings obtained as a result of the analysis of the demographic characteristics of the tourists indicated that the education and income levels of the tourists who participated in the co-creation were high. Likewise, in the studies carried out in the United States by Park and Ha (2016) and in Turkey by Arıca and Kozak (2019); it was found that the education and income levels of the tourists who purchased the touristic products through the co-creation were high. This finding can be interpreted in terms that the touristic services co-created with customers are preferred by the tourists with high education and income levels.

\section{CONCLUSION}

The customer participation in value creation explains how the customers provide input into the production stages in line with their requests and needs in terms of product design, new product development, and personalization of services. Tourism businesses are able to determine the requests and needs of tourists by means of the value co-creation with customers and thus produce the personalized products that are in line with the requests and needs of the customers (Groth, 2004; Prebensen \& Xie, 2017). In this regard, the value co-creation with customers makes it possible for the tourism businesses to offer the differentiated options as an alternative to the mass offers dominant in the market. The personalized productions not only enable the tourism businesses to differentiate in the market, but also improve the customers' value judgments and satisfaction levels regarding the touristic experience (Ford \& Heaton, 2000; Prebensen \& Xie, 2017). That being said, the results of this study reveal that the customers' participation in the value co-creation improves the satisfaction. This indicates that practicing the strategy of value co-creation with customers in the tourism businesses will help the businesses in differentiating their services and ensuring the customer satisfaction in the 
tourism market. Grissemann and Stokburger-Sauer (2012) asserted that the development of the value perceptions and satisfaction of tourists would contribute to the improvement of the financial indicators of the businesses. In this regard, it is obvious that the value co-creation with customers will function in the improvement of both the non-financial and financial performance outputs and make significant contributions to the competitiveness and continuity of the businesses.

Assiouras et al. (2019) suggest that as the perception of tourists towards the service develop, their citizenship behavior towards the business and experience will also develop. This argument is supported in the present study. According to the results of the study, the value cocreation with customers improves the citizenship behavior of the tourists. The customer citizenship behavior is effective in increasing the quality of experience, gaining marketing opportunities, and influencing the preference of the potential tourist groups who have similar interests. Accessing these opportunities is only possible for the businesses if they can develop the tolerance, helping, advocacy, and feedback behaviors, which the tourists display before, during, and after the experience. The tourists who have a high level of citizenship behavior towards the business and the touristic experience, exhibit a constructive attitude when they encounter a fault in the service or business, help the customers who are in a difficult situation during the experience, provide positive feedbacks to the business and employees, and support the process of developing and improving services. These situations explain that the customers who develop a citizenship behavior take extra responsibilities and make efforts to improve the quality of the experience (Groth, 2004). As it is observed in the results of the study, the participation of customers in the value co-creation enables them to display advocacy behaviors and, in turn, the tourists who develop an advocacy behavior have a higher level of satisfaction. In this regard, it is obvious that the value co-creation with customers will contribute to the development of tourists' advocacy and thus to the enhancement of the satisfaction of tourists. Being displayed offline or online, the advocacy behavior can be used as one of the important marketing tools in today's market. So, the tourists can influence the decision-making processes by recommending the business and employees in offline platforms to the potential tourists such as friends or families (Buhalis \& Sinarta, 2019). The tourists can also display an advocacy behavior for the business and touristic experience in an online platform. Due to the developments in the information and communication technologies, the social communication networks have become a strategically important medium where the 
information is shared online between the customers and between the business and customer (Law et al., 2014; Buhalis \& Sinarta, 2019). As emphasized by Rihova et al. (2018), the widespread use of the social communication networks increases the sphere of influence of the posts shared in these networks. The widespread use of social networks such as Facebook, Twitter, Instagram and travel consultant and the increase of the shares of consumers in this field expands the domain of their shares in these fields (Arıca, 2019). Tourists significantly influence the potential tourist groups having similar interests by means of their sharings in the social networks, and the experiences shared in this way serve as a stimulant in the decision-making processes of the tourists (Groth, 2004; Chan \& Guillet, 2011). So, creating platforms for the value co-creation with customers ensures the development of the advocacy behavior for the business and touristic experience and by doing so, improves the satisfaction of the tourists; contributes to the marketing activities of the business; and supports the business in retaining the existing customers and gaining new ones.

The effect of the value co-creation with customers on the delivered and perceived service outputs, the financial performance indicators of the businesses, the citizenship behavior, and the satisfaction of tourists requires the integration of the structure of the value co-creation with customers into the business processes of the tourism companies. Adoption of the strategy of value co-creation with customers by the businesses contributes to gaining a long-term competitive advantage, strengthening their sectoral position, and ensuring a sustainable development. There are a number of requirements for the businesses to optimize the benefits of the strategy they practice. The most important of these requirements is the development of the systems to support the active participation of tourists in production (Buhalis \& Sinarta, 2019). These systems play a major role in realizing the value co-creation with customers and strengthening the employeecustomer, customer-company, and customer-customer interaction. Therefore, it is important for the businesses to adapt the co-creation infrastructure modules, which will support the processes before, during, and after the tourist travels, to the business processes. By this means, it will be possible for the businesses to understand the requests, needs, and preferences of the tourists before, during, and after the travel experiences and a structure will be established to facilitate the interaction with the tourists. Systems should be designed in a way that all tourists can understand the processes and everyone can participate in the production (Chan \& Guillet, 2011; Buhalis \& Sinarta, 2019). Furthermore, the processes 
designed for the co-creation with customers should be supported by the technological devices and systems, and some platforms should be created to support the interaction. By the same token, it is essential to establish the feedback platforms, to ensure the sustainability in the auditing through the social communication networks, and to create systems that ensure the analysis and evaluation of the feedbacks received from the customers through these networks. The success in value co-creation with customers and the infrastructure investments depends largely on the skills of the employees (Etgar, 2008). Therefore, the businesses should employ the personnel who have a high technological knowledge and awareness required to use this structure efficiently. In this regard, it is important for the businesses to employ the individuals who can manage their own business within their responsibility and authority, have advanced communication and analysis skills, and create a synergy and team spirit.

\section{Limitations and recommendations}

Although the research reached some important results in general, there are also some limitations. It is possible to test the measurement model used in the research in different sample sets and at different times in the tourism sector. Thus, the scope of the research results can be expanded. This study focused on the effect of value co-creation with customers on the citizenship behavior of tourists. When the relevant literature is examined, it is seen that the value co-creation with customers has been generally evaluated in terms of the customer-oriented outputs. In this regard, in future studies, examining the value co-creation with customers from the perspective of management and addressing the business-oriented outputs will contribute to the holistic evaluation of the outputs to be obtained through this strategy. In addition, a possible field of research is the assessment of the changes to be caused by the products differentiated through the value co-creation with customers in the tourism market and the examination of the future production structures.

\section{REFERENCES}

Alpar, R. (2010). Spor, Sağlık ve Eğitim Bilimlerinden Örneklerle Uygulamalı İstatistik ve Geçerlik-Güvenirlik. Ankara: Detay Yayıncılık.

Arıca, R. (2019). Seyahat acentalarında turistik ürünlerin kişişelleştirilmesinin bir yolu olarak müşterilerle üretim. Türk Turizm Araştırmaları Dergisi, 3(3), 499-516. 
Arıca, R., \& Kozak, R. (2018). Seyahat acentalarında müşterilerin üretime katılım davranışının algılanan hizmet çıktılarına etkisi. Seyahat ve Otel İşletmeciliği Dergisi, 15(3), 684-702.

Arıca, R., \& Kozak, R. (2019). Co-production behaviors of travel agencies customers: A research on local cultural tourists visiting Istanbul. Journal of Tourism and Hospitality Management, 7(1), 84-98.

Arnould, E. J. (2008). Service-dominant logic and resource theory. Journal of Academic Marketing Science, 36, 21-24.

Assiouras, I., Skourtis, G., Giannopoulos, A., Buhalis, D., \& Koniordos, M. (2019). Value co-creation and customer citizenship behavior. Annals of Tourism Research, 78, 1027422. https://doi.org/10.1016/j.annals.2019.102742

Barnes, C., Mattsson, J., \& Sorensen, F. (2014). Destination brand experience and visitor behavior. Testing a scale in the tourism context. Annals of Tourism Research, 48, 121139.

Bason, C. (2010). Leading Public Sector Innovation: Co-Creating for a Better Society. Bristol: Policy Press.

Bell, L., \& Baybak, A. (2018). Customer satisfaction as an antecedent to engagement in cocreation of value in the hotel industry. Journal of Tourism and Hospitality Management, 6(2), 13-25.

Blazquez-Resino, J. J., Morlina, A., \& Esteban-Talaya, A. (2015). Service-dominant logic in tourism: The way to loyalty. Current Issues in Tourism, 18(8), 706-724.

Buhalis, D., \& Sinarta, Y. (2019). Real-time co-creation and nowness service: Lessons from tourism and hospitality. Journal of Travel \& Tourism Marketing, 36(5), 563-582.

Cassia, F., Ugolini, M., Cobelli, N., \& Gill, L. (2014). Service-based vs. goods-based positioning of the offering-effects on customer perceived value. 17th Toulon-Verona International Conference Excellence in Services (pp. 51-58). Liverpool: Liverpool John Moores University.

Chan, N., \& Guillet, D. (2011). Investigation of social media marketing: How does the hotel industry in Hong Kong perform in marketing on social media websites? Journal of Travel \& Tourism Marketing, 28(4), 345-368.

Chan, K. W., Yim, C. K., \& Lam, S. S. K. (2010). Is customer participation in value creation a double-edged sword? Evidence from professional financial services across cultures. Journal of Marketing, 74(3), 48-64.

Çokluk, Ö., Şekercioğlu, G., \& Büyüköztürk, Ş. (2016). Sosyal Bilimler İçin Çok Değgişkenli İstatistik SPSS ve LISREL Uygulamaları (4. Baskı). Ankara: Pegem Akademi.

Etgar, M. (2008). A descriptive model of the consumer co-production process. Journal of the Academic Marketing Science, 36, 97-108.

Fitzpatrick, M., Davey, J., Muller, L., \& Davey, H. (2013). Value-creating assets in tourism management: Applying marketing's service-dominant logic in the hotel industry. Tourism Management, 36, 86-98.

Flores, F., \& Vasquez-Parraga, A. Z. (2015). The impact of choice on co-produced customer value creation and satisfaction. Journal of Consumer Marketing, 32(1), 15-25.

Ford, W. S. Z. (1995). Evaluation of the indirect influence of courteous service on customer discretionary behavior. Human Communication Research, 22(1), 65-89.

Ford, R. C., \& Heaton, C. P. (2000). Managing the Guest Experience in Hospitality. New Jersey: Delmar.

Fornell, C., \& Larcker, D. F. (1981). Evaluating structural equation models with unobservable variables and measurement error. Journal of Marketing Research, 18(1), 39-50. 
Gong, T., \& Yi, Y. (2019). A review of customer citizenship behaviors in the service context. The Service Industries Journal. DOI: 10.1080/02642069.2019.1680641.

Grissemann, U. S., \& Stokburger-Sauer, N. E. (2012). Customer co-creation of travel services: The role of company support and customer satisfaction with the cocreation performance. Tourism Management, 33, 1483-1492.

Groth, M. (2004). Customers as good soldiers: Examining citizenship behaviors in internet service deliveries. Journal of Management, 31(1), 7-27.

Hair, J. F., Black, W. C., Babin, B. J., \& Anderson, R. E. (2010). Multivariate Data Analysis (Seventh edition). New York: Pearson Publications.

Hoyer, W. D., Chandy, R., Dorotic, M., Krafft, M., \& Singh, S. S. (2010). Consumer cocreation in new production development. Journal of Service Research, 13(3), 283-296.

Huang, C. C., Wang, Y. M., Wu, T. W., \& Wang, P. A. (2013). An empirical analysis of the antecedents and performance consequences of using the Moodle platform. International Journal of Information and Education Technology, 3(2), 217-221.

Kalaycı, Ş. (2016). Spss Uygulamalı Çok Değişkenli İstatistik Teknikleri (7. Baskı). Ankara: Asil Yayın Dağıtım.

Kelley, S. W., Donnelly, J. H., \& Skinner, S. J. (1990). Customer participation in service production and delivery. Journal of Retailing, 66(3), 315-335.

Law, R., Buhalis, D., \& Çobanoğlu, C. (2014). Progress on information and communication technologies in hospitality and tourism. International Journal of Contemporary Hospitality Management, 26(5), 727-750.

Li, X., \& Petrick, J. F. (2008). Tourism marketing in an era of paradigm shift. Journal of Travel Research, 46(3), 235-244.

Namasivayam, K., \& Guchait, P. (2013). The role of contingent self-esteem and trust in consumer satisfaction: Examining perceived control and fairness as predictors. International Journal of Hospitality Management, 33, 184-195.

Oxenswardh, A. (2018). Processes of value co-creation at a tourist accommodation. Quality Innovation Prosperity, 22(3), 36-53.

Park, J., \& Ha, S. (2016). Co-creation of service recovery: Utilitarian and hedonic value and post-recovery responses. Journal of Retailing and Consumer Services, 28, 310-316.

Parks, R. B., Baker, P. C., Kiser, L., Oakerson, R., Ostrom, E., Ostrom, V., Percy, S. L., Vandivort, M. B., Whitaker, G. P., \& Wilson, R. (1981). Consumers as co-producers of public services: Some economic and institutional considerations. Policy Studies Journal, 9(7), 1001-1011.

Phi, G., \& Dredge, D. (2019). Critical issues in tourism co-creation. Tourism Recreation Research, 44(3), 281-283.

Prahalad, C. K., \& Ramaswamy, V. (2004). The Future of Competition: Co-Creation Unique Value with Customers. Boston: Harvard Business School Press.

Prebensen, N. K., Kim, H., \& Uysal, M. (2015). Cocreation as moderator between the experience value and satisfaction relationship. Journal of Travel Research, 55(7), 934935.

Prebensen, N. K., Vitterso, J., \& Dahl, T. I. (2013). Value co-creation significance of tourist resources. Annals of Tourism Research, 42, 240-261.

Prebensen, N. K., \& Xie, J. (2017). Efficacy of co-creation and mastering on perceived value and satisfaction in tourists' consumption. Tourism Management, 60, 166-176.

Ranjan, K. R., \& Read, S. (2014). Value co-creation: Concept and measurement. Journal of the Academy of Marketing Science, 44(3), 290-315. 
Rihova, I., Buhalis, D., Gouthro, M. B., \& Moital, M. (2018). Customer-to-customer cocreation practices in tourism: Lessons from customer-dominant logic. Tourism Management, 67, 362-375.

Sugathan, P., Ranjan, K. R., \&. Mulky, A. G. (2017). Atypical shifts post-failure: Influence of co-creation on attribution and future motivation to co-create. Journal of Interactive Marketing, 38, 64-81.

Tabachnick, B. G., \& Fidell, L. S. (1996). Using Multivariate Statistics. New York: Harper Collins College Publishers.

Taşkın, Ç., \& Akat, Ö. (2010). Araştırma Yöntemlerinde Yapısal Eşitlik Modelleme. LISREL İle Marka Değeri Ölçümü Örnekleri. Bursa: Ekin Basım Yayın Dağıtım.

Ulaga, W., \& Chacour, S. (2001). Measuring customer-perceived value in business markets: A prerequisite for marketing strategy development and implementation. Industrial Marketing Management, 30, 525-540.

Van Doorn, J., Lemon, K. N., Mittal, V., Nass, S., Pick, D., Pirner, P., \& Verhoef, P. C. (2010). Customer engagement behavior: Theoretical foundations and research directions. Journal of Service Research, 13(3), 253-266.

Vargo, S. L., \& Lusch, R. F. (2004). Evolving to a new dominant logic for marketing. Journal of Marketing, 68, 1-17.

Vargo, S. L., \& Lusch, R. F. (2008). Service-dominant logic: Continuing the evolution. Journal of the Academy of Marketing Science, 36(1), 1-10.

Vargo, S., Maglio, P., \& Akaka, M. (2008). On value and value co-creation: A service systems and service logic perspective. European Management Journal, 26(3), 145-152.

Yaşlıoğlu, M. M., (2017). Sosyal bilimlerde faktör analizi ve geçerlilik: Keşfedici ve doğrulayıcı factor analizlerinin kullanılması. Istanbul University Journal of the School of Business, 46, 74-85.

Yi, Y., \& Gong, T. (2013). Customer value co-creation behaviour: Scale development and validation. Journal of Business Research, 66, 1279-1284. 